\title{
Tidal movements of East Pacific green turtle Chelonia mydas at a foraging area in Baja California Sur, México
}

\author{
Louise B. Brooks ${ }^{1, *}$, James T. Harvey ${ }^{1}$, Wallace J. Nichols ${ }^{2}$ \\ ${ }^{1}$ Moss Landing Marine Laboratories, 8272 Moss Landing Road, Moss Landing, 95039, USA \\ ${ }^{2}$ California Academy of Sciences, 875 Howard Street, San Francisco, 94103, USA
}

\begin{abstract}
We tracked East Pacific green turtles Chelonia mydas using GPS-VHF telemetry in Estero Banderitas, a tidally-influenced foraging area in Bahía Magdalena, Baja California Sur, México. Tidal currents were measured with a bottom-mounted Acoustic Doppler Profiler (ADP) and the data used to predict tidal current speed and direction at the location and time during which turtles were tracked. Twenty-nine turtles were tracked in the summers of 2000 to 2003. Vagility $\left(\right.$ mean $\left.\pm \mathrm{SD}_{;} 18.6 \pm 11.4 \mathrm{~km} \mathrm{~d}^{-1}\right)$ and speed $\left(0.83 \pm 0.47 \mathrm{~km} \mathrm{~h}^{-1}\right)$ of turtles was the greatest so far reported for green turtles at foraging areas. Turtles displayed highly linear movements, and movement patterns were circatidal. Vector correlation was used to compare turtle speed and direction with tidal speed and direction. Correlation coefficients were significant for 11 out of 13 tracks, indicating significant linear interdependence between turtles and tides. Speed and direction contributed equally to the correlation. Results indicated a new paradigm for green turtles in feeding areas, where turtles are transported on continual tides that allow them to exploit a patchy and seasonal distribution of algae, their main diet component. This tidal transport is markedly different than Selective Tidal Stream Transport, in which animals use either the ebb or flood tide for transport. Tidal currents may be an accurate indicator of turtle movement in tidal areas, and this transport system has implications for foraging ecology, energetics, and growth.
\end{abstract}

KEY WORDS: Green turtle $\cdot$ Tidal movements $\cdot$ East Pacific Ocean · Wildlife telemetry · Foraging · Acoustic Doppler Profiler

Resale or republication not permitted without written consent of the publisher

\section{INTRODUCTION}

The East Pacific green turtle Chelonia mydas, like many sea turtle species and sub-populations worldwide, has experienced a dramatic decrease in numbers in the last century. Some populations, such as those at Ascension Island, show signs of recovery (Broderick et al. 2006), but green turtles in the East Pacific are currently listed as endangered by the World Conservation Union (Hilton-Taylor 2000) and are protected by international and national law (Aridjis 1990). Although nesting beaches in this region (e.g. Colola and Maruata, Michoacán, México) are well monitored, the subpopulation continues to suffer from direct and inciden- tal take at areas used for feeding (hereafter called feeding areas) in northwestern México (Alvarado \& Figueroa 1995, Alvarado-Diaz et al. 2001, Seminoff 2004). An estimated 8359 to 33397 turtles are killed each year at northern feeding areas off the Baja California peninsula (Mancini 2009, Mancini et al. unpubl.), such as Estero Banderitas, our study site, which is located within Bahía Magdalena.

Less is known about the ecology of the herbivorous green turtle at feeding areas than on nesting beaches (Mortimer 1981, Bjorndal 1997). Recent studies of feeding ecology have provided new information on diet, activity, movement, and home range. Environmental factors, such as water temperature, time of day, 
and location of food affect activity and movement patterns of green turtles in feeding areas (Bjorndal 1980, Mendonça 1983, Ogden et al. 1983, Limpus \& Limpus 2000, Seminoff et al. 2002b, Taquet et al. 2006). In general, green turtles exhibit a bimodal pattern of movement, feeding in the early morning and late afternoon, and resting in deeper waters during midday and at night (Bjorndal 1980, Mendonça 1983, Ogden et al. 1983, Seminoff et al. 2002b, Taquet et al. 2006). In nontidal foraging areas, food availability is the main determinant of green turtle activity (Bjorndal 1980, Ross 1985, Balazs et al. 1987) while in areas where tidal currents are a dominant environmental force, it is possible that tides become the most important determinant of activity and movements.

Ocean currents affect the movements of turtles undergoing large-scale migrations (Luschi et al. 2003a, Girard et al. 2006), and tidally-oriented movements have been observed for green, loggerhead Caretta caretta and Kemp's ridley Lepidochelys kempii sea turtles in tidal feeding areas (Byles 1988, Limpus et al. 1994, Limpus \& Limpus 2000, Schmid et al. 2002). However, rarely have tidal currents been considered an important environmental factor affecting green turtles at feeding areas.

Use of Selective Tidal Stream Transport (STST) is well documented in fishes and invertebrates (Forward \& Tankersley 2001). Animals use either ebb-tide or flood-tide transport, and may make use of both strategies on different occasions or during different stages of their life history. At all stages, such transport is considered energetically beneficial (Forward \& Tankersley 2001). In the case of turtle movements, however, the 'selective' component of the behavior associated with STST appears to be absent, and animals instead move with the ebb and flood tide in sequential and continuous fashion (Brooks et al. 2004). Several species of fish also exhibit similar movement patterns, often termed 'passive drift' (Teaf 1980, Almeida 1996, Ackerman et al. 2000).

Preliminary data on green turtles in Estero Banderitas indicated a strong correlation between turtle movement and tidal currents (Brooks et al. 2004). The purpose of the present study was to investigate the extent to which tidal currents affect the movements of green turtles at a tidally-influenced feeding area. We hypothesized that (1) daily movements and foraging activities would be strongly affected by tidal currents, (2) turtles would exhibit circatidal rhythms, and (3) the direction and speed of turtle movement would be directly related to the direction and speed of the tidal currents. To obtain quantitative local tide data, we deployed Acoustic Doppler Profilers (ADPs). We tracked turtles with GPS-VHF telemetry and compared data on turtle speed and direction with tidal speed and direction as measured by the ADPs.

\section{MATERIALS AND METHODS}

Study area. The Bahía Magdalena-Almejas complex is located on the Pacific Coast of Baja California Sur,

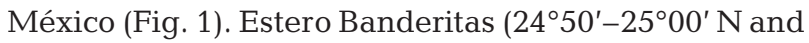
$112^{\circ} 05^{\prime}-112^{\circ} 08^{\prime} \mathrm{W}$ ) is an evaporative basin located in the northern zone of Bahía Magdalena. The roughly $42 \mathrm{~km}^{2}$ lagoon is the largest in the complex. Three species of mangroves (Avicennia germinans, Laguncularia racemos, and Rhizophora mangle) line the main waterway and the meandering side lagoons, which are characterized by deeper channels in the center and shallower mud and sand flats on the edges. The substrate consists of sand and mud with patches of algae and seagrass beds. The area is heavily influenced by tidal currents, with salinity and temperature increasing near the head of the basin (Brooks et al. 2008). Average salinity at the mouth of Estero Banderitas is between 36.9 and 38.7 (Alvarez-Borrego et al. 1975), average water temperatures are 18 to $31^{\circ} \mathrm{C}$, and depth is 1 to $9 \mathrm{~m}$. Green turtles are the most abundant species of sea turtle in the area, although loggerhead and hawksbill Eretomochelys imbricata turtles are also encountered.

Tides. We measured tidal currents with a bottommounted SONTEK Acoustic Doppler Profiler (ADP). Water motion was measured every $0.25 \mathrm{~cm}$ (cell depth) within the water column. Data were recorded in $120 \mathrm{~s}$ on / $120 \mathrm{~s}$ off intervals and then averaged for the interval. This reduced Doppler noise to less than $1 \mathrm{~cm} \mathrm{~s}^{-1}$. Tides were sampled at 10 systematically selected locations (stations) throughout the study site for a minimum of $48 \mathrm{~h}$ at each station (Fig. 1)

The direction, height, and speed of tidal currents during ADP deployment at each station was determined using a program written in MATLAB Version 6.5 (MathWorks). Along-channel current direction was determined by corroborating ADP-measured angles of flow with known channel orientations on a chart of the region. Direction of flow $\left( \pm 1^{\circ}\right)$ was calculated for ebb and flood currents for each of 5 levels of current speed (divided into $0.2 \mathrm{~m} \mathrm{~s}^{-1}$ increments, from 0.0 to $1.0 \mathrm{~m} \mathrm{~s}^{-1}$ ).

Water height was estimated by counting the number of $0.25 \mathrm{~m}$ cells sampled by the ADP from the bottom to the surface. Harmonic regression was used to correct for the measurement error $( \pm 0.25 \mathrm{~m})$. We calculated the change in height vs. the change in time $(\Delta H / \Delta t)$ for each measured half-tidal period ( $6 \mathrm{~h}$; low to high, high to low).

Tidal current velocities were separated into alongchannel $(V)$ and across-channel $(U)$ components using a program written in MATLAB. Velocity measurements $\left( \pm 0.01 \mathrm{~m} \mathrm{~s}^{-1}\right)$ were averaged for the depth of the water column. We determined an along-channel maximum speed ( $V_{\max }$ ) for each measured half-tidal period. These calculations were performed for each ADP sta- 


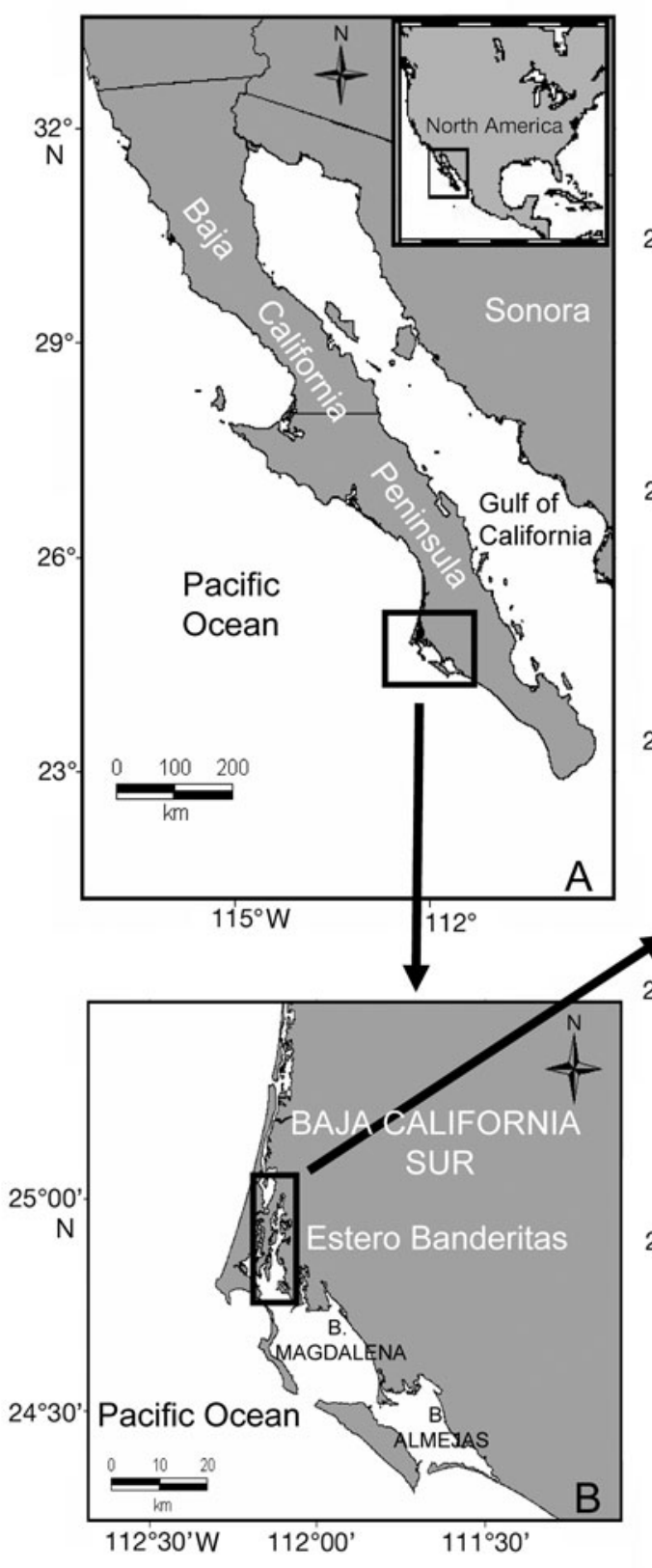

tion. Eq. (1) (Sverdrup et al. 1947) establishes that $V_{\max }$ is proportional to the change in height vs. a change in time:

$$
V_{\max }=\frac{4}{3} \frac{\pi}{T} \frac{A}{S} 2 h
$$

where $A$ is the surface area, $S$ the cross-sectional area of the opening to the basin, $h$ is the tidal range, $V_{\max }$ is the maximum velocity through a channel connecting the open sea to a basin and $T$ is $1 / 2$ ( $6 \mathrm{~h}$ ) of a tidal cycle.

Based on this relationship, we used a series of linear regressions to compare the change in tidal height over the change in time in San Diego, California, USA (the closest known tidal station with actual measurements rather than predictions) (San Diego $\Delta H / \Delta t$ ) with the

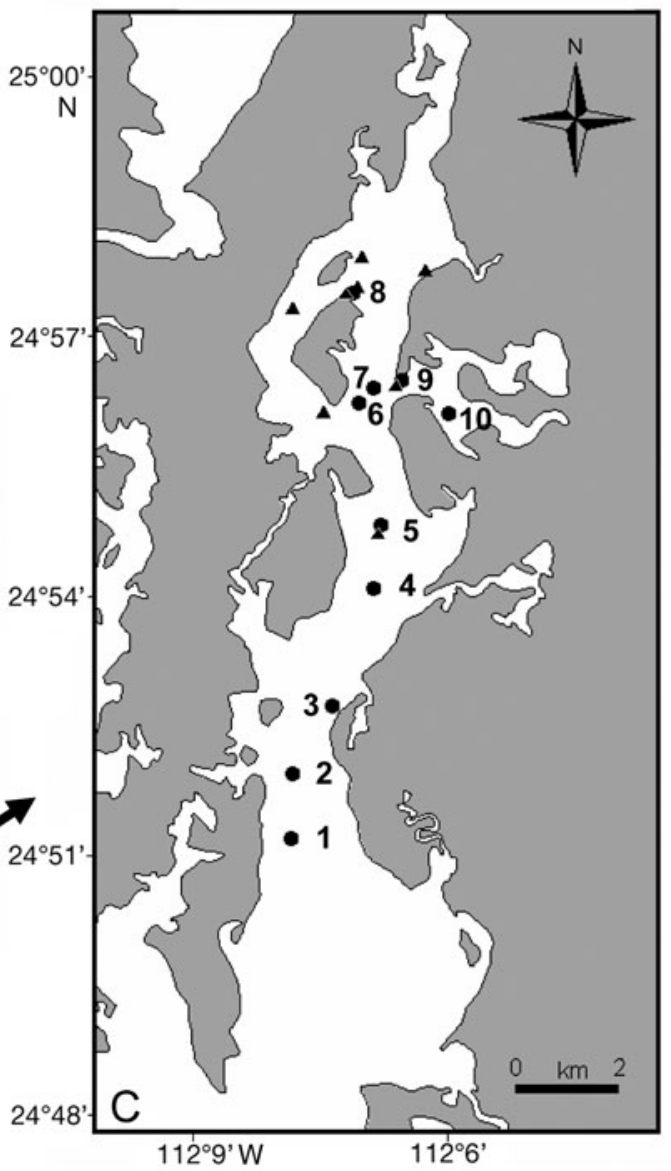

Fig. 1. (A) Baja California Peninsula. (B) Bahía Magdalena-Almejas Complex. (C) Estero Banderitas, Baja California Sur, México:

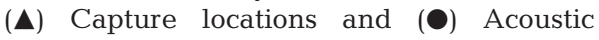
Doppler Profiler (ADP) Stations 1 to 10

change in tidal height over the change in time at each tidal station (Station $\Delta H / \Delta t$ ), and Station $\Delta H / \Delta t$ with the maximum velocity of the current at each tidal station (Station $V_{\max }$ ). Regression equations were used to predict $V_{\max }$ of the tidal current at times when data were not available. Once $V_{\max }$ was predicted, we used sine interpolation (Eq. 2) to interpolate the along-channel current speed at a desired time $\left(T_{i}\right)$ between the times of known current velocities of zero, or slack tides $\left(T_{1}\right.$ and $\left.T_{2}\right)$ :

$$
V_{i}=V_{\max } \times \sin \left(180 \frac{\left(T_{i}-T_{1}\right)}{\left(T_{2}-T_{1}\right)}\right)
$$

Current speed was predicted for the time midway through each $0.5 \mathrm{~h}$ interval of turtle movement for each 
turtle track. Once the speed of the tide was predicted, the corresponding direction of flow was determined. These estimates resulted in a tidal vector, consisting of speed and direction, predicted for each $0.5 \mathrm{~h}$ interval during each turtle track and at the corresponding geographical location of the turtle. We compared these tidal vectors to turtle vectors, as explained in 'Turtles' below.

Turtles. We captured and tracked sea turtles in Estero Banderitas during the summer seasons of 2000 to 2003. Turtles were captured using entanglement nets (100 m long, $25 \mathrm{~cm}$ mesh size) set at 8 locations throughout the study site (Fig. 1). Nets were set day and night, and monitored continuously for captured turtles. Captured turtles were removed from the net and placed in the shade in a boat or a padded holding box $(1.5 \times 1.5 \mathrm{~m})$. We recorded body mass $(\mathrm{kg} \pm 1 \mathrm{~kg})$, standard length (straight carapace length [SCL], measured notch to tip of longest marginal scute, $\pm 0.1 \mathrm{~cm}$ ), and curved length (curved carapace length [CCL], measured with flexible tape along longest line, $\pm 0.1 \mathrm{~cm}$ ). Tail length (TTL) was measured from the posterior edge of the plastron to the tip of the tail using calipers $( \pm 0.1 \mathrm{~cm})$. Turtles were tagged on each rear flipper with metal Inconel tags (National Band and Tag Company, Newport), adjacent to the first large scale (Balazs 1999). All turtles were released at the capture location within $10 \mathrm{~h}$ of capture, but always at a similar point in the tidal cycle to that at which they were captured. For example, if a turtle was caught early in the flood tide, it was released at that point in the subsequent tide. Turtles were allowed to acclimate for $3 \mathrm{~h}$ before track data were used.

A 2-sample $t$-test was used to compare the mean SCL of turtles tracked to the mean SCL of all turtles captured in Estero Banderitas. We used a 1-way ANOVA to test for differences in mean SCL of tracked turtles among years. For these and all subsequent statistical analyses, $\alpha=0.05$.

We tracked turtles using GPS-VHF telemetry. The telemetry unit consisted of a floating, PVC plastic cylinder (15 cm long, $7 \mathrm{~cm}$ diameter) containing a VHF transmitter, a $10 \mathrm{~m}$ monofilament line as a tether, and a carapace attachment (Brooks et al. 2008). VHF transmitters were 3 to $5 \mathrm{~cm}$ in length and 2 to $3 \mathrm{~cm}$ in width, and transmitted at 164-165 MHz. For the first $3 \mathrm{yr}$, a kayaker followed each tagged turtle for the duration of tracking. Turtle positions were recorded every $15 \mathrm{~min}$ by the kayaker using a Garmin Geko or Mariner handheld GPS unit.

In 2003, a GPS unit was housed in the tracking float, and GPS locations $( \pm 3 \mathrm{~m}$ ) were recorded every $2 \mathrm{~min}$. A VHF transmitter was attached to the top of the cylinder and monitored to locate the unit. We measured the force imposed on the turtle due to the tag in a Multiscale Flow Analysis System (MFAS).
A $5.2 \mathrm{~m}$ Boston Whaler was used to monitor the turtles regularly throughout the tracking period from a distance of $>50 \mathrm{~m}$ so as not to affect the behavior of the turtle. Closer and unobtrusive observations were conducted by swimmers and kayakers. Termination of the tracking period occurred when either the attachment broke under natural conditions, or we reached our desired tracking period, and the unit was removed from the turtle by gathering in the monofilament line, breaking it at the carapace attachment point.

GPS positions were downloaded from the handheld unit using Waypoint+ (Hildebrand 2000) and analyzed with MATLAB. We wrote MATLAB programs to determine speed and course of turtle movement and length of the track. Tracks were divided into 30 min segments, and the mean speed and course of the turtle was calculated for each segment. Mean, maximum, and minimum speeds of each turtle were calculated for each track. Duration of time at zero speed, or rest duration, was also calculated. The tracks were mapped using MATLAB and ArcView.

Tracks were designated as neap or spring tide tracks if they fell within $1 \mathrm{~d}$ of neap or spring tide. Track segments were designated as 'day' if they occurred between 08:00 and 18:00 h, and as 'night' if they occurred between 21:00 and 05:00 h. We used 2-sample $t$-tests to compare mean kilometers traveled per $24 \mathrm{~h}$ day (vagility), mean speed, and maximum speed between tracks at neap and spring tides, and to compare mean speed between day and night tracks. Linear regressions were used to determine whether mean speed and vagility were dependent on turtle size (SCL).

Mean speed of turtles and tides were compared using a 2-sample $t$-test. Speed and direction of turtles and tides during $0.5 \mathrm{~h}$ intervals were averaged. Tidal current speed and direction were predicted for the midpoint of the $0.5 \mathrm{~h}$ interval. Other day and times were not included in the analysis. We plotted the resultant vectors, one for each $0.5 \mathrm{~h}$ of each track, using stick plots to show magnitude (speed) and direction (course of travel) for turtles and tides. Vectors for turtle and tide were analyzed using vector correlation as defined by Crosby et al. (1993) and Breaker et al. (1994). This technique allowed us to analyze the vector quantity, inclusive of magnitude and direction, rather than the 2 scalar $(x$ and $y$ ) components separately, which provided a more comprehensive analysis of the relationship. The sample correlation coefficient, $\mathrm{r}^{2}$, is a measure of linear interdependence and ranges from 0.0 for no correlation to 2.0 for perfect correlation (due to working with 2 dimensions; Breaker et al. 1994). To assess significance of the correlation, 95th percentile limits were determined using cumulative frequency distributions for 2-dimensional vectors for the sample size of interest ( $\mathrm{n}=$ number of vectors; Breaker et al. 1994). 


\section{RESULTS}

Tides

Tides were measured at each tidal station for 48.7 to $117.1 \mathrm{~h}$. Data from 8 stations were compared with turtle tracks in 2003. Stn 6 was not used due to its proximity with $\operatorname{Stn} 7$. Stn 8 was located at the corner of an island where tidal currents were confounding; therefore, data were of limited use. Tidal range, or change in height, was $2.8 \mathrm{~m}$ at full moon spring tide and $1.1 \mathrm{~m}$ at quarter moon neap tide.

Mean along-channel current speed per station was $0.29 \pm 0.13 \mathrm{~m} \mathrm{~s}^{-1}$ (mean $\pm \mathrm{SD}$; range: 0.11 to $0.46 \mathrm{~m} \mathrm{~s}^{-1}$ ). The maximum along-channel current speed, $0.93 \mathrm{~m}$ $\mathrm{s}^{-1}$, occurred during the full moon spring tide at Stn 2 . Along-channel speeds were an order of magnitude greater than across-channel speeds (Brooks 2005).

Linear regression indicated a significant relationship between San Diego $\Delta H / \Delta t$ and Station $\Delta H / \Delta t$, and between $V_{\max }$ and Station $\Delta H / \Delta t$, illustrating the relationship described in Eq. (1). Greater regression coefficients and a lower standard error for the estimate indicated that the relationship between $V_{\max }$ and $\Delta H / \Delta t$ was well described.

\section{Turtles}

Force imposed by the tag ranged from $<1 \mathrm{~g}\left(9.8 \times 10^{-3} \mathrm{~N}\right)$ at currents $<$ $0.34 \mathrm{~m} \mathrm{~s}^{-1}(0.7 \mathrm{kn})$ to $265.0 \mathrm{~g}(2.6 \mathrm{~N})$ at currents of $0.92 \mathrm{~m} \mathrm{~s}^{-1}(\sim 2 \mathrm{kn})$. The \% turtle biomass equivalent to this range of tag forces, obtained comparing tension $(\mathrm{g})$ to the mean turtle mass $(22.3 \pm$ $1.86 \mathrm{~kg}$ ), was 0 to $1.2 \%$ of mean turtle biomass.

Data from 29 turtles tracked during the 2000 to 2003 seasons were analyzed (Tables $1 \& 2$ ). SCL of tracked turtles were 43.9 to $68.9 \mathrm{~cm}$ (54.5 \pm $5.8 \mathrm{~cm})$. CCL of tracked turtles was 45.5 to $70.1 \mathrm{~cm}(58.0 \pm 5.8 \mathrm{~cm})$. Recapture rate increased during the years of the study. In 2003, more than half of turtles tracked had been captured at an earlier date during associated monitoring studies. Turtles were caught at all 8 netting locations and tracked in July, and August. Turtles were caught during the day and at night, and during slack and flowing tides. Substrates at capture locations were rocks, mud, and sand. Turtles were tracked for 5.2 to $53.0 \mathrm{~h}$
$(24.5 \pm 13.5 \mathrm{~h})$ and traveled 1.4 to $65.3 \mathrm{~km}$. All telemetry units were recovered successfully at termination of tracking and all turtles were safely released.

There was no significant difference in the SCL of turtles tracked among years $(F=0.90, \mathrm{p}=0.45$, df $=3$ ). The mean SCL of turtles tracked $(54.5 \pm 5.8 \mathrm{~cm})$ also did not differ significantly from the mean SCL of all 184 turtles captured during the project $(53.7 \pm 8.2 \mathrm{~cm}$; $t=0.53, \mathrm{p}=0.600, \mathrm{df}=182$ ). All turtles tracked were juveniles, therefore sex was undetermined.

Area of use, indicated by tracks, was similar among years (Fig. 2). Turtles were tracked in the main channel and side lagoons. They used the entire length of Estero Banderitas, but no turtle was ever tracked outside the estero. Turtles used the deeper, center channel of waterways, and rarely were tracked over shallow mudflats. Movements were dependent somewhat on where the turtle was captured. For example, those turtles captured in the side channel near tidal Station 9 (see Fig. 2) used this area more than those captured in the main channel.

Turtles traveled at speeds of 0 to $1.45 \mathrm{~m} \mathrm{~s}^{-1}$ (0 to $5.22 \mathrm{~km} \mathrm{~h}^{-1}$ ). Mean speed for all turtles tracked was $0.23 \pm 0.13 \mathrm{~m} \mathrm{~s}^{-1}\left(0.83 \pm 0.47 \mathrm{~km} \mathrm{~h}^{-1}\right)$. Vagility, or dis-

Table 1. Capture and morphological data for turtles tracked in Estero Banderitas, Baja California Sur, México, between July and August, 2000 to 2003. SCL: straight carapace length; CCL: curved carapace length; TTL: tail length

\begin{tabular}{|c|c|c|c|c|c|c|}
\hline Turtle ID & $\begin{array}{l}\text { Capture } \\
\text { date }\end{array}$ & $\begin{array}{l}\text { Recapture } \\
\text { (Y/N) }\end{array}$ & $\begin{array}{l}\text { SCL } \\
(\mathrm{cm})\end{array}$ & $\begin{array}{l}\text { CCL } \\
(\mathrm{cm})\end{array}$ & $\begin{array}{l}\text { Body mass } \\
\quad(\mathrm{kg})\end{array}$ & $\begin{array}{l}\text { TTL } \\
(\mathrm{cm})\end{array}$ \\
\hline Turtle 2 & 6 Jul 2000 & $\mathrm{~N}$ & 48.8 & 52.0 & 15.9 & 8.7 \\
\hline Turtle 3 & 7 Jul 2000 & $\mathrm{~N}$ & 53.2 & 55.5 & $\mathrm{n} / \mathrm{a}$ & $\mathrm{n} / \mathrm{a}$ \\
\hline Turtle 4 & 7 Jul 2000 & $\mathrm{~N}$ & 55.3 & 59.0 & 13.6 & $\mathrm{n} / \mathrm{a}$ \\
\hline Turtle 5 & $23 \mathrm{Jul} 2000$ & $\mathrm{~N}$ & 46.2 & 49.5 & 12.7 & 6.3 \\
\hline Turtle 6 & $23 \mathrm{Jul} 2000$ & $\mathrm{~N}$ & 50.3 & 53.7 & 16.8 & 8.8 \\
\hline Turtle 7 & 9 Jul 2001 & $\mathrm{~N}$ & 52.4 & 56.7 & 17.2 & 9.5 \\
\hline Turtle 8 & 12 Jul 2001 & $\mathrm{Y}$ & 66.1 & 70.1 & 39.9 & 12.6 \\
\hline Turtle 10 & 25 Jul 2001 & $\mathrm{~N}$ & 52.0 & 55.5 & 18.1 & 9.5 \\
\hline Turtle 11 & 7 Jul 2002 & $\mathrm{Y}$ & 50.4 & 53.1 & 17.7 & 9.1 \\
\hline Turtle 12 & 10 Jul 2002 & $\mathrm{~N}$ & 50.0 & 53.4 & 17.7 & 8.7 \\
\hline Turtle 13 & 10 Jul 2002 & $\mathrm{Y}$ & 51.5 & $\mathrm{n} / \mathrm{a}$ & 19.1 & 6.4 \\
\hline Turtle 14 & 18 Jul 2002 & $\mathrm{~N}$ & 56.3 & 61.2 & 25.9 & 10.9 \\
\hline Turtle 15 & 23 Jul 2002 & $\mathrm{~N}$ & 53.5 & 56.6 & 20.4 & 11.2 \\
\hline Turtle 16 & 24 Jul 2002 & $\mathrm{~N}$ & 55.4 & 61.1 & 24.2 & 11.1 \\
\hline Turtle 18 & 28 Jul 2002 & $\mathrm{~N}$ & 60.8 & 65.0 & 32.7 & 12.7 \\
\hline Turtle 19 & 29 Jul 2002 & $\mathrm{~N}$ & 64.0 & 68.5 & 36.3 & 11.0 \\
\hline Turtle A & 1 Jul 2003 & $\mathrm{Y}$ & 55.9 & 58.1 & 21.8 & 12.9 \\
\hline Turtle B & 3 Jul 2003 & $\mathrm{~N}$ & 47.3 & 55.0 & 12.5 & 8.5 \\
\hline Turtle C & 3 Jul 2003 & $\mathrm{Y}$ & 53.6 & 57.0 & 22.0 & 7.4 \\
\hline Turtle D & 7 Jul 2003 & $\mathrm{~N}$ & 53.6 & 56.7 & 21.0 & 8.2 \\
\hline Turtle E & 8 Jul 2003 & $\mathrm{Y}$ & 68.9 & $\mathrm{n} / \mathrm{a}$ & $\mathrm{n} / \mathrm{a}$ & $\mathrm{n} / \mathrm{a}$ \\
\hline Turtle F & 11 Jul 2003 & $\mathrm{Y}$ & 58.6 & 63.2 & 25.9 & 9.8 \\
\hline Turtle G & 14 Jul 2003 & $\mathrm{Y}$ & 59.0 & 63.5 & 24.4 & 10.8 \\
\hline Turtle H & 22 Jul 2003 & $\mathrm{Y}$ & 53.1 & 56.5 & 21.0 & 11.2 \\
\hline Turtle I & 24 Jul 2003 & $\mathrm{~N}$ & 54.8 & 59.6 & 19.8 & 9.7 \\
\hline Turtle J & 24 Jul 2003 & $\mathrm{~N}$ & 56.4 & 61.1 & 23.8 & 10.9 \\
\hline Turtle K & 28 Jul 2003 & $\mathrm{~N}$ & 48.1 & 50.8 & 17.6 & 5.8 \\
\hline Turtle L & 1 Aug 2003 & $\mathrm{Y}$ & 63.5 & 67.0 & 26.3 & 16.6 \\
\hline Turtle M & 1 Aug 2003 & $\mathrm{~N}$ & 43.9 & 45.5 & 9.1 & 6.1 \\
\hline
\end{tabular}


Table 2. Track data for turtles tracked in Estero Banderitas, between July and August, 2000-2003. Spring/Neap indicates tidal state at time of tracking; $\mathrm{r}^{2}$ is the correlation coefficient for vector correlation. ${ }^{*}$ Turtle speed and direction vector was significantly correlated with the tidal speed and direction vector. NA: not available

\begin{tabular}{|lrrlrrr|}
\hline Turtle ID & $\begin{array}{c}\text { Time } \\
\text { tracked } \\
(\mathrm{h})\end{array}$ & $\begin{array}{c}\text { Distance } \\
\text { tracked } \\
(\mathrm{km})\end{array}$ & $\begin{array}{c}\text { Spring/ } \\
\text { Neap }\end{array}$ & $\begin{array}{r}\text { Speed } \\
\text { range } \\
\left(\mathrm{m} \mathrm{s}^{-1}\right)\end{array}$ & $\begin{array}{r}\text { Mean } \\
\text { speed } \\
\left(\mathrm{m} \mathrm{s}^{-1}\right)\end{array}$ & $\mathrm{r}^{2}$ \\
\hline Turtle 2 & 33.7 & 28.9 & & $0.01-1.51$ & 0.32 & NA \\
Turtle 3 & 16.3 & 8.8 & Neap & $0-0.62$ & 0.17 & NA \\
Turtle 4 & 19.1 & 4.5 & Neap & $0-0.40$ & 0.07 & NA \\
Turtle 5 & 46.7 & 52.8 & & $0.01-1.23$ & 0.31 & NA \\
Turtle 6 & 46.9 & 65.3 & Spring & $0.01-1.45$ & 0.38 & NA \\
Turtle 7 & 10.0 & 9.0 & & $0-1.42$ & 0.26 & NA \\
Turtle 8 & 11.2 & 11.7 & Neap & $0.02-0.96$ & 0.28 & NA \\
Turtle 10 & 45.3 & 8.9 & Neap & $0-0.26$ & 0.06 & NA \\
Turtle 11 & 24.6 & 28.8 & & $0.01-1.10$ & 0.34 & NA \\
Turtle 12 & 22.1 & 32.9 & Spring & $0.02-1.44$ & 0.40 & NA \\
Turtle 13 & 23.0 & 26.5 & Spring & $0-1.13$ & 0.31 & NA \\
Turtle 14 & 23.9 & 10.0 & & $0-0.54$ & 0.12 & NA \\
Turtle 15 & 23.7 & 35.8 & Spring & $0.01-0.97$ & 0.40 & NA \\
Turtle 16 & 23.8 & 38.6 & Spring & $0.02-1.20$ & 0.44 & NA \\
Turtle 18 & 6.9 & 10.9 & & $0.04-0.77$ & 0.43 & NA \\
Turtle 19 & 12.9 & 17.6 & & $0.05-0.91$ & 0.39 & NA \\
Turtle A & 5.2 & 4.7 & & $0-0.53$ & 0.25 & 0.41 \\
Turtle B & 25.5 & 29.1 & & $0.01-0.73$ & 0.35 & $0.71^{*}$ \\
Turtle C & 18.7 & 11.2 & & $0.01-0.96$ & 0.36 & $0.90^{*}$ \\
Turtle D & 51.3 & 47.7 & Spring & $0-1.13$ & 0.44 & $1.02^{*}$ \\
Turtle E & 28.3 & 12.1 & & $0-0.72$ & 0.16 & $0.38^{*}$ \\
Turtle F & 12.0 & 13.4 & Spring & $0-1.41$ & 0.45 & $1.35^{*}$ \\
Turtle G & 53.0 & 46.7 & Spring & $0-0.97$ & 0.29 & $0.96^{*}$ \\
Turtle H & 8.7 & 1.4 & Neap & $0-0.40$ & 0.05 & $0.68^{*}$ \\
Turtle I & 38.5 & 30.5 & Neap & $0-0.92$ & 0.24 & $0.67^{*}$ \\
Turtle J & 22.0 & 7.2 & & $0-0.53$ & 0.11 & $0.36^{*}$ \\
Turtle K & 20.7 & 2.8 & Spring & $0-0.33$ & 0.04 & 0.05 \\
Turtle L & 21.3 & 21.1 & & $0-0.92$ & 0.28 & $0.60^{*}$ \\
Turtle M & 16.5 & 6.2 & & $0-0.52$ & 0.11 & $0.35^{*}$ \\
\hline
\end{tabular}

was not in the conventional method of remaining in one place for an extended (> $1 \mathrm{~h}$ ) amount of time. Investigative dives at these locations found no significant cover of algae or seagrass, indicating that turtles were not feeding at these locations.

Stick plots indicated a similarity between tidal speed and direction and turtle speed and direction through time (Fig. 3). There was no significant difference between mean turtle speeds and mean current speeds measured during the same time period ( $t=0.44, \mathrm{p}=0.666$, $\mathrm{df}=14)$. There was a significant vector correlation between movements of turtles and tidal currents for 11 of the 13 turtle tracks for which data were available (Table 2). Correlation was significant during all tidal phases (spring and neap), and for tracks occurring throughout the length of the Estero Banderitas. Correlations for 2 tracks, including Turtle A (Fig. 3), were insignificant.

\section{DISCUSSION}

Tides

Physical environmental factors, such as tides, affect the ecology of marine animals but rarely are quantitative

tance traveled per $24 \mathrm{~h}$ day, was 3.3 to $38.9 \mathrm{~km} \mathrm{~d}^{-1}$ $\left(\right.$ mean $\left.=18.6 \pm 11.4 \mathrm{~km} \mathrm{~d}^{-1}\right)$. Speed did not differ between day and night $(t=1.54, \mathrm{p}=0.13$, df $=29)$. Speed and vagility were independent of turtle SCL (speed: $F=0.47, \mathrm{p}=0.50, \mathrm{df}=27$; vagility: $F=0.30, \mathrm{p}=$ 0.64 , df $=27$ ).

We tracked 6 turtles during neap tide and 9 turtles during spring tide. Turtles traveled a greater mean distance during spring tide $\left(28.9 \pm 11.3 \mathrm{~km} \mathrm{~d}^{-1}\right)$ than during neap tide $\left(9.8 \pm 8.3 \mathrm{~km} \mathrm{~d}^{-1} ; t=-3.55, \mathrm{p}=0.004, \mathrm{df}=\right.$ 13). Turtles maintained a greater mean speed during spring tide $\left(0.35 \pm 0.13 \mathrm{~ms}^{-1}\right)$ than during neap tide $\left(0.12 \pm 0.01 \mathrm{~m} \mathrm{~s}^{-1} ; t=-3.81, \mathrm{p}=0.002, \mathrm{df}=13\right)$. Mean maximum speeds also were significantly greater during spring tide $\left(1.12 \pm 0.35 \mathrm{~ms}^{-1}\right)$ compared with neap tide $\left(0.50 \pm 0.25 \mathrm{~m} \mathrm{~s}^{-1} ; t=-3.9, \mathrm{p}=0.003, \mathrm{df}=13\right)$.

Periods of rest, or zero movement, were infrequent and short. During 2003, when positions were determined every 2 min, 18 tracks had speeds of zero at some point during the track, but the maximum duration of zero speed was $16 \mathrm{~min}$. If turtles were resting, it methods applied to evaluate this relationship. This study represents one of the first in which tidal currents were quantitatively measured and compared with movements of a large marine vertebrate, in this case sea turtles.

Vector correlation, to our knowledge, has not been used to assess the similarity between tidal and animal movement. Vector correlation was used previously to analyze wind and current samples in a time series (Breaker et al. 1994), but is applicable to any analysis in which two vectors are compared. By comparing quantities as vectors, rather than scalar components, we avoided problems associated with correlating circular, or directional, data and allowed the effects of both scalar quantities to be compared as a single entity (Crosby et al. 1993). As with all statistical measures, a greater sample size affords greater confidence in the results, and minimizes correlation with small sample sizes ( $<10$ ind.) that were due to chance. For example, results for Turtle A, where 11 samples were obtained, should be interpreted with caution. 

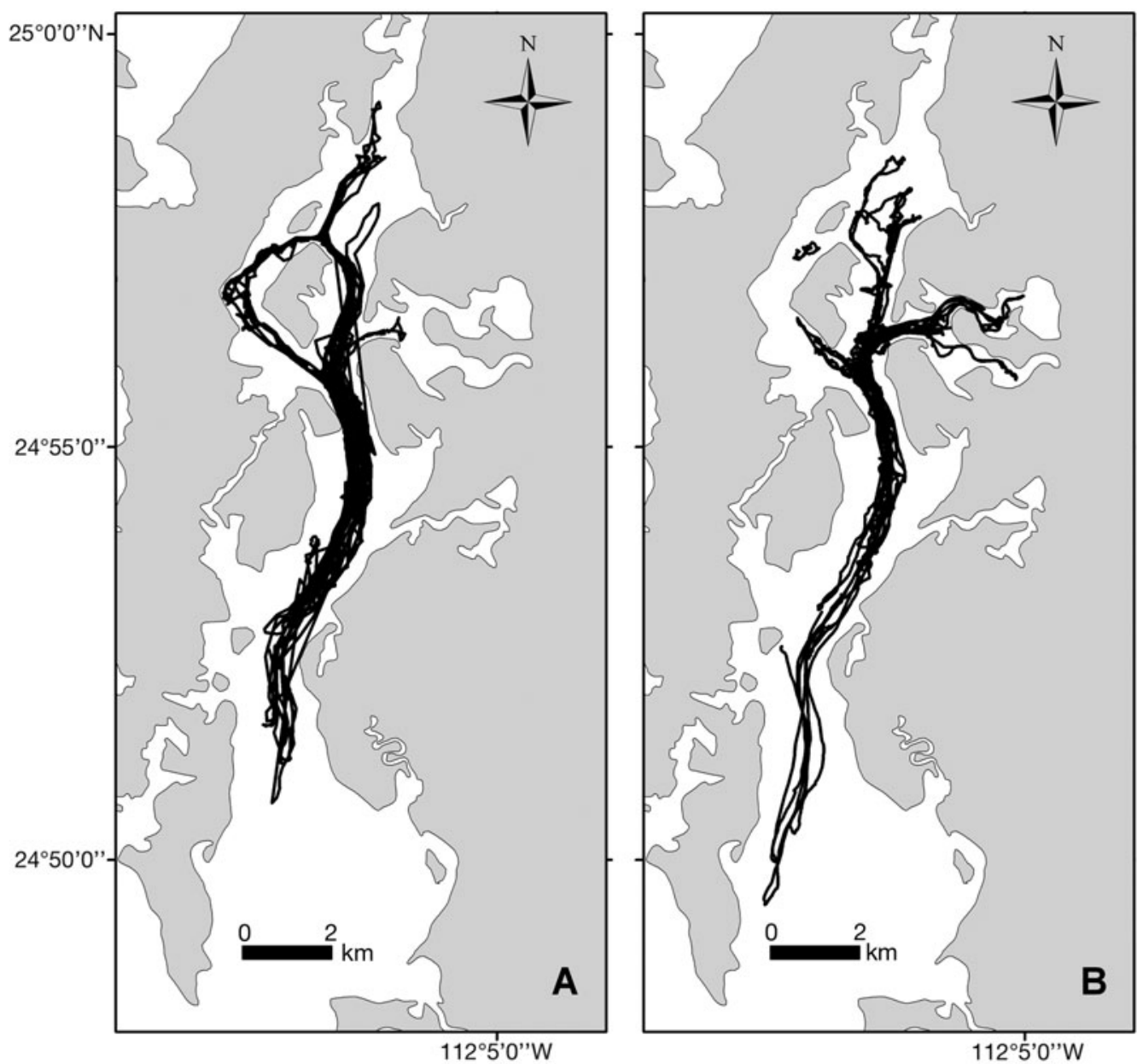

Fig. 2. Chelonia mydas. Composite of movements for all individuals tracked using GPS-VHF telemetry in Estero Banderitas, BCS, México. (A) July and August, 2000-2002 (n = 16). (B) July and August $2003(n=13)$
A greater sample size, or longer time series, also allows for analysis through time. We calculated a single value to obtain a correlation coefficient for the entire record which was a meaningful analysis of the entire track. With greater sample sizes, one could observe the variation in correlation through the duration of the record by using a moving window. For example, it would be possible to determine where in the tidal cycle vector correlation was the greatest, during mid-tide or slack tide, or ebb or flood tide.

\section{Turtles}

Tracking of marine turtles has increased in recent years with the improvement of telemetry technology. Satellite telemetry, the most highly developed technique, is used worldwide as it is well suited for recording large-scale migrations on the order of 100s of kilometers. Due to limitations in scale and accuracy of the position fixes, it is generally unsuitable for tracking in a local foraging habitat where fine-scale data (error $<1 \mathrm{~km}$ ) are needed (Godley et al. 2003). Tracking in foraging areas has been undertaken using acoustic and VHF telemetry (Mendonça 1983, Ogden et al. 1983, Brill et al. 1995, Schmid et al. 2002, Seminoff et al. 2002b, Schmid et al. 2003). This method can be somewhat inaccurate, timeconsuming, and yield a relatively small amount of fixes. GPS telemetry in marine vertebrates has been limited because of the required acquisition time, as diving animals rarely spend enough time at the surface to achieve a fix by the GPS unit. Recent technological advances have developed GPS tags to overcome this, and success has been seen in fine-scale tracking of marine turtles (Yasuda \& Arai 2005). We overcame the challenge of acquisition time by using a buoyant housing that kept the GPS unit at the surface for most of the time. Location of the turtle and GPS positions were recorded throughout the tracking period. The technique yielded $>10000$ highquality data points, with an error of $\pm 3 \mathrm{~m}$. The failsafe design allowed for safe detachment and release of the floating housing and tether if accidental entanglement occurred, or when we terminated tracking. A $10 \mathrm{~m}$ long connection between the turtle and the buoyant housing was chosen because water depth was usually $<10 \mathrm{~m}$ throughout Estero Banderitas, so that the turtles did not 


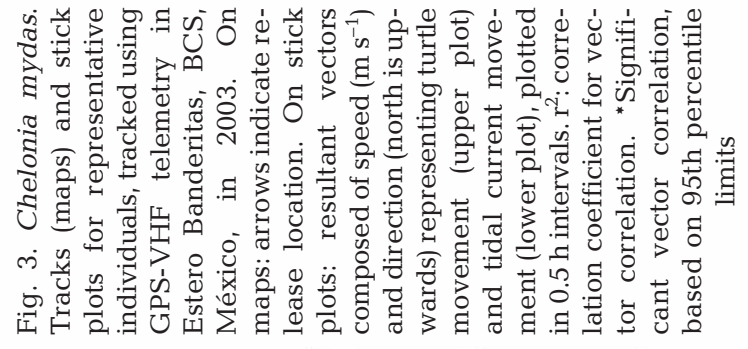

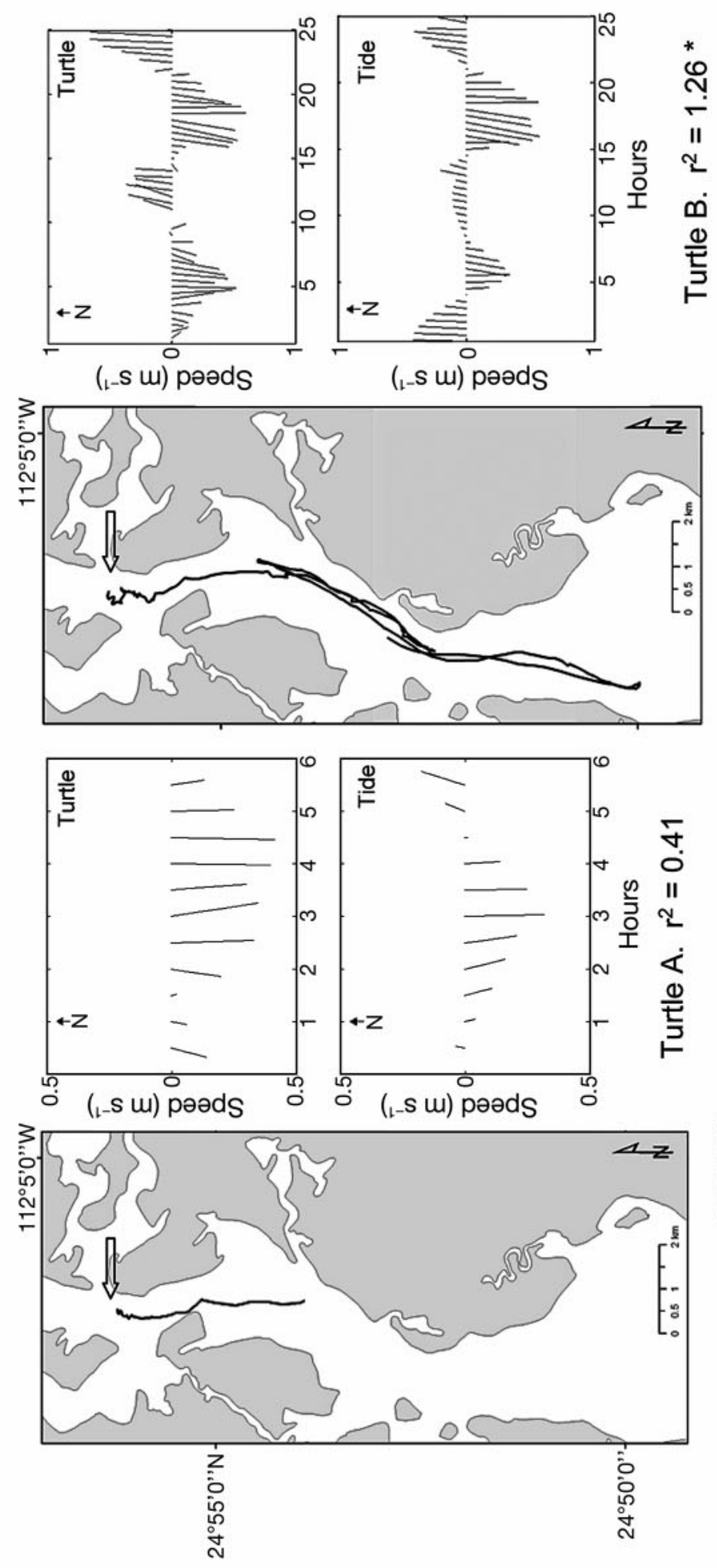
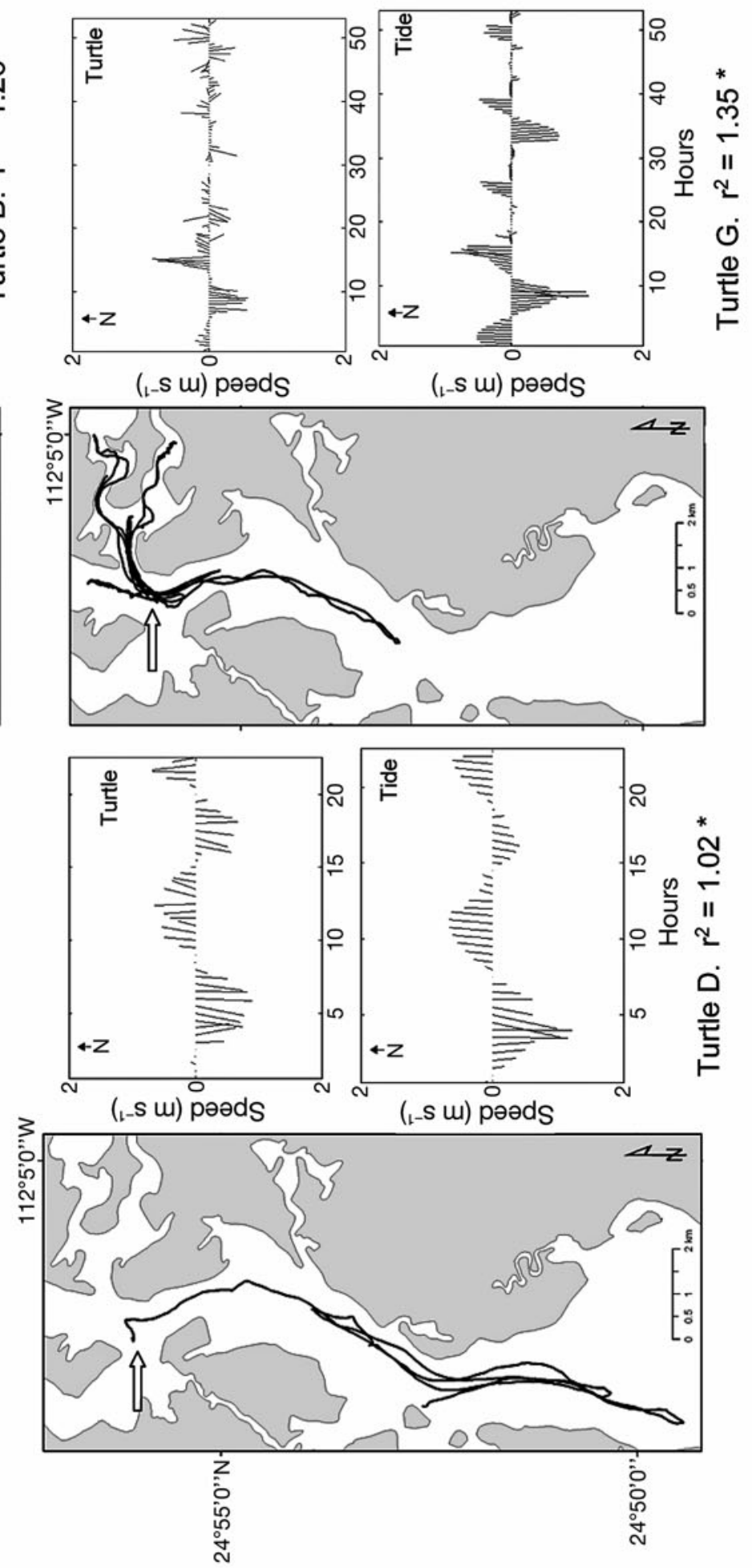
drag the housing under water and there was minimal extra line in the water.

The force of the tag as measured with the MFAS compares favorably with other studies on telemetered animals. Seminoff et al. (2002b) reported the maximum mass of their radio and sonic telemetry unit to be $1.2 \%$ of the body mass of tagged green turtles. The 0 to $1.2 \%$ of tag vs. body mass for our study was less than the maximum tag:mass ratio of $2 \%$ recommended based on studies of telemetered fish (Mellas \& Haynes 1985).

Turtles tracked in Estero Banderitas were representative of the juvenile stock found in the area. No turtles tracked vacated the area during tracking, and none of the 184 individuals captured in Estero Banderitas was recaptured at outside locations during capture efforts for associated research (V. Koch pers. comm.). Possible explanations for the increase in recapture rate include a higher percentage of tagged turtles in the population and/or individual affinity for nets. Personal observations revealed that some released turtles swam back into a nearby net.

Green turtles in Estero Banderitas traveled further and faster than those found in other feeding areas. Vagility measured during spring tides is the greatest reported for green turtles at any feeding area (Mendonça 1983, Ogden et al. 1983, Brill et al. 1995, Renaud et al. 1995, Seminoff 2000; Table 3). Mean vagility measured at neap tide in Estero Banderitas is comparable with maximum vagility reported at other sites. This is understandable, as it is during neap tides when tidal influence is minimal and Estero Banderitas is most similar to non-tidal habitats.

Speed, or rate of movement, of green turtles has been reported less frequently. Speed of green turtle movements in Estero Banderitas $\left(0.83 \pm 0.47 \mathrm{~km} \mathrm{~h}^{-1}\right)$ was the greatest so far reported for sea turtles in feeding areas, and can be compared, for example, with $0.33 \pm 0.09 \mathrm{~km} \mathrm{~h}^{-1}$ for green turtles in Bahía de los Angeles (Seminoff \& Jones 2006), 0.4 to $1.4 \mathrm{~km} \mathrm{~h}^{-1}$ for loggerhead turtles in the Gulf of México (Renaud \& Carpenter 1994), and $0.44 \pm 0.33 \mathrm{~km} \mathrm{~h}^{-1}$ (range: 0.004 to $1.758 \mathrm{~km} \mathrm{~h}^{-1}$ ) for Kemp's ridley turtles in Cedar Keys, Florida (Schmid et al. 2002). It is of note that Kemp's ridley turtles, which moved at the next greatest speeds, also moved with tidal currents.

We do not expect that turtles in Estero Banderitas were swimming faster than turtles in other feeding areas. Rather, we believe that the greater vagility and speed of green turtles were due to transport by tidal currents. Other sea turtles move quickly within currents. Leatherback turtles traveled at maximum speeds of $6 \mathrm{~km} \mathrm{~h}^{-1}$ in the Agulhas Current in the Indian Ocean, a current with water speeds of up to $7.2 \mathrm{~km} \mathrm{~h}^{-1}$ (Luschi et al. 2003b).

Tides were the greatest determinant of movement and activity patterns in Estero Banderitas. Greater tidal currents resulted in greater distances traveled, greater mean speeds, and greater maximum speeds compared to lesser, neap currents. Transport distance and speed did not depend on turtle size, as has been shown for juvenile green turtles in Texas (Arms 1996), or time of day. Turtle tracks were mostly linear, and replicated the inward and outward movement of the tide. Stick plots provided a unique way to observe the similarity between the movement of turtles and tides, and to visually analyze the effects of the direction and speed simultaneously. Vector correlation provided a quantitative measurement of this similarity, and the majority of turtle movements were significantly correlated with tidal movements as indicated by $\mathrm{r}^{2}$ values. The similarity of both the direction and speed component of the vectors indicated that more than scalar factors contributed to a significant correlation. Differences in the direction of turtles and currents were observed with a time lag between the tide changing directions and the turtle changing directions. Differences in speed may have been due to the vertical position of the turtle in the water column. We used a mean velocity for the entire water column to determine tidal vectors, but turtles on feeding grounds dive from the surface to the bottom at regular intervals. Vertical profile data illustrated a variation in velocity throughout the water column. Utilizing a time-depth recorder in future studies would help address this issue. Also, we expect that turtles are not always passive drifters on the horizontal scale, but occasionally swim in different directions to that of the tidal flow.

Turtles maintained themselves in the center of the channel, which corresponds to the fastest currents

Table 3. Chelonia mydas. Summary of vagility (distance traveled per day) reported from different foraging areas. ${ }^{*}$ Different units

\begin{tabular}{|lcl|}
\hline Location & Vagility & \multicolumn{1}{c|}{ Source } \\
\hline Estero Banderitas, BCS, México & $\begin{array}{c}29.9 \pm 11.3 \mathrm{~km} \\
\text { (spring tide, summer) } \\
9.8 \pm 9.3 \mathrm{~km} \\
\end{array}$ & Present study \\
& (neap tide, summer) & \\
Mosquito Lagoon, FL, USA & $8.2 \pm 1.75 \mathrm{~km}$ (winter) & Mendonça (1983) \\
& $2.62 \pm 0.96 \mathrm{~km}$ (summer) & \\
St. Croix, US Virgin Islands & $\sim 2 \mathrm{~km}$ & Ogden et al. (1983) \\
Hawaii, USA & $3 \mathrm{~km}^{2}$ area over 13 d* & Brill et al. (1995) \\
Texas, USA & $1.2 \mathrm{~km}$ & Renaud et al. (1995) \\
Bahía de los Angeles, BC, México & $9.54 \pm 3.2 \mathrm{~km}$ (summer) & Seminoff (2000) \\
\hline
\end{tabular}


along the width of the channel. We are unsure whether dynamics of flow keep turtles entrained within the strongest currents or whether turtles actively steer themselves so they remain in the greatest current speed in the center of the channel. Further research on the 3-dimensional location of turtles within the water column would help answer these questions.

Movements of green turtles in Estero Banderitas were unlike tracks reported from non-tidal feeding areas, where turtles followed a diel pattern and polygonal movements were suited to their bay-like habitats. The paucity of periods of no movement indicated that turtles in Estero Banderitas were not resting outside of the tidal currents. Data collected underwater, such as that from a carapace-mounted camera (Hays et al. 2007) or from acceleration data loggers (Yoda et al. 2001), might indicate whether turtles were actively moving their flippers (i.e. swimming) during movement, or whether they were drifting and essentially motionless. If they were not swimming for substantial periods throughout the day, resting during tidal transport might be sufficient to satisfy energetic needs.

Most feeding studies of green turtles describe the presence of large pastures of dense seagrass or algae in the foraging habitat (Bjorndal 1980, Mendonça \& Ehrhart 1982, Ogden et al. 1983, Seminoff et al. 2002a). In Estero Banderitas, distribution and abundance of algae is patchy (Ramos \& Santos 2005; L. B. Brooks \& J. T. Harvey unpubl. data). The lack of persistent pastures on which to feed means that turtles cannot depend on a food source in one particular place. Whiting \& Miller (1998) proposed that the distribution of food over a wide area in Repulse Bay, Australia, resulted in greater movements of foraging green turtles. Similarly, green turtles in Estero Banderitas must travel long distances to find food. The local environment is ideally suited to this need by providing strong tidal currents by which turtles can travel at low energetic cost.

Our study is the first to quantitatively measure the influence of tides on green turtles. Previous studies have shown that tidal currents affect movements of loggerhead turtles in Chesapeake Bay (Byles 1988), Kemp's ridley turtles in Cedar Keys, Florida (Schmid et al. 2002), USA, and green turtles in Queensland, Australia (Limpus \& Limpus 2000). Researchers in these studies noted the potential benefit of using currents for conserving energy. If turtles in Estero Banderitas swim less than turtles in other feeding areas, we might expect a consequential conservation of energy and increased growth. The mean growth rate of turtles in Estero Banderitas, at large for at least $12 \mathrm{mo}$, was $1.7 \pm$ $0.6 \mathrm{~cm} \mathrm{yr}^{-1}$, with growth rates 3 times greater in summer than in winter (Koch et al. 2007). These rates are comparable to the reported $1.4 \mathrm{~cm} \mathrm{yr}^{-1}$ mean growth rate for green turtles in Bahía de los Angeles (Seminoff et al. 2002c), despite habitat differences between the 2 sites. The lack of difference between the growth rates may result from a balance of environmental factors. Though turtles in Bahía de los Angeles must swim between feeding and resting sites, they experience a greater abundance of food and decreased travel distances. In contrast, turtles in Estero Banderitas must travel long distances to encounter sufficient food, but tides provide energetically advantageous transport. Both stocks might also be experiencing a similar decrease in food availability and/or foraging activity in winter as water temperatures decrease. This is evidenced by slow winter growth at Estero Banderitas. Green turtles at other sites in the Gulf of California and Pacific lagoons go into torpor, a type of hibernation, during winter months (Felger et al. 1976, Nichols 2003). Winter growth in Bahía de los Angeles has not been investigated.

A critical component of STST is vertical migration of the animal in the water column to control the direction of horizontal movement. The lack of this behavior in green turtles indicated a similar but notably new transport pattern. Green turtles in Estero Banderitas were transported continuously, with sequential ebb and flood tides, throughout the tidal cycle, rather than traveling selectively upstream or downstream. If planktonic animals, such as larvae, can avoid undesirable tidal currents, we would expect green turtles to have the same ability and to demonstrate it on a regular basis, as needed. However, as turtles are not being displaced unfavorably by tidal transport, they have no reason to avoid it. Instead, they probably need the transport to effectively exploit food resources in Estero Banderitas.

We anticipate that these data may be applicable to the behavior of turtles in other tidally-dominated areas worldwide, and to potential management plans for these areas. In habitats with strong tidal currents, turtles are probably moving with the tides. Conducting studies of turtle movement can be costly in terms of both time and money, but tidal information is often more readily available. In areas with more available information on tides than on turtles, turtle movement could potentially be predicted using tidal data.

Our data indicate a new paradigm for green turtles in tidal foraging areas and a new transport system for animals in high energy tidal systems. Long-term monitoring will continue to provide information on residence times, population size, and habitat use. Future studies may investigate turtle transport on a 3-dimensional scale, flow dynamics within a tidal current, algal density and distribution, and energetics and feeding activity, to create a more complete assessment of the foraging ecology of green turtles in this, and other, tidally-dominated habitats. 
Acknowledgements. Thanks to W. Broenkow for technical advice, W. Watson for tag engineering, S. Flora for MATLAB help, L. Breaker for vector correlation instruction, V. Koch, R. Rangel, J. Solis, Grupo Tortuguero de las Californias, and SFS students and staff for field assistance, and J. Adams, H. Nevins, and the MLML Vertebrate Ecology Lab for assistance. Funding was provided by the National Fish and Wildlife Foundation (NFWF), the Homeland Foundation, the Lerner Gray Foundation, Myers Oceanographic Trust, the PADI Foundation, and a Harvey Graduate Research Fellowship. Research was conducted under permit \# 280499.213.03 1565 and \# 280700.213.03 2619, authorized by Secretaria de Medio Ambiente Recursos Naturales y Pesca, Estado Unidos de México. The animal care protocol was approved by the SJSU Animal Care and Use Committee (IACUC \#805).

\section{LITERATURE CITED}

Ackerman JT, Kondratieff MC, Matern SA, Cech JJ (2000) Tidal influence on spatial dynamics of leopard sharks, Triakis semifasciata, in Tomales Bay, California. Environ Biol Fishes 58:33-43

Almeida PR (1996) Estuarine movement patterns of adult thin-lipped grey mullet, Liza ramada (Risso) (Pisces, Mugilidae), observed by ultrasonic tracking. J Exp Mar Biol Ecol 202:137-150

Alvarado J, Figueroa A (1995) East Pacific green sea turtle, Chelonia mydas. In: Plotkin PT (ed) Status reviews for sea turtles listed under the Endangered Species Act of 1973. National Marine Fisheries Service, Silver Spring, MD

Alvarado-Diaz J, Delgado-Trejo C, Suazo-Ortuno I (2001) Evaluation of the black turtle project in Michoacán, México. Mar Turtle Newsl 92:4-7

Alvarez-Borrego S, Galindo-Bect LA, Chee-Barragan A (1975) Caracteristicas hidroquimicas de Bahia Magdalena, BCS. Cienc Mar 2:94-110

Aridjis H (1990) México proclaims a total ban of harvest of turtles and eggs. Mar Turtle Newsl 50:1-3

Arms SA (1996) Overwintering behavior and movement if immature green sea turtles in South Texan waters. MSc Thesis, Texas A\&M University

Balazs GH (1999) Factors to consider in the tagging of sea turtles. In: Eckert KL, Bjorndal KA, Abreu-Grobois FA, Donnelly $M$ (eds) Research and management techniques for the conservation of sea turtles. IUCN/SSC Marine Turtle Specialist Group Publication No. 4, p 101-109

Balazs GH, Forsyth RG, Kam AKH (1987) Preliminary assessment of habitat utilization by Hawaiian green turtles in their resident foraging pastures, US Dept of Commerce, NOAA Tech Mem, NMFS, NOAA-TM-NMFS-SWFC-71

Bjorndal KA (1980) Nutritional and grazing behavior of the green turtle Chelonia mydas. Mar Biol 56:147-154

Bjorndal KA (1997) Foraging ecology and nutrition of sea turtles. In: Lutz PL, Musick JA (eds) The biology of sea turtles. CRC Press, Boca Raton, FL, p 199-232

> Breaker LC, Gemmill WH, Crosby DS (1994) The application of a technique for vector correlation to problems in meteorology and oceanography. J Appl Meteorol 33:1354-1365

Brill RW, Balazs GH, Holland KN, Chang RKC, Sullivan S, George JC (1995) Daily movements, habitat use and submergence intervals of normal and tumor-bearing juvenile green turtles (Chelonia mydas) within a foraging area in the Hawaiian islands. J Exp Mar Biol Ecol 185:203-218

Broderick AC, Frauenstein R, Glen F, Hays GC and others (2006) Are green turtles globally endangered? Glob Ecol Biogeogr 15:21-26
Brooks LB (2005) Abundance and tidal movements of green turtle (Chelonia mydas) in B.C.S., México. MS thesis, San José State University, San José, CA

Brooks LB, Nichols WJ, Koch V, Hernandez A (2004) Preliminary results on the distribution and movement of green turtles, Chelonia mydas, in Estero Banderitas, Baja California Sur, México. In: Coyne, MS and Clark, RD (eds) Proc 21st Ann Symp Sea Turtle Biology and Conservation. NOAA Tech Mem NMFS-SEFSC-528, p 127-128

Brooks LB, Harvey JT, Nichols WJ (2008) Tethered GPS/VHF transmitters: a high-tech, low-cost toll for fine scale, inwater tracks. In: Mast RB, Hutchinson BJ, Hutchinson AH (eds) Proc 24th Ann Symp Sea Turtle Biology and Conservation. NOAA Tech Mem NMFS-SEFSC-567, p 189

Byles RA (1988) Behavior and ecology of sea turtles from Chesapeake Bay, Virginia. PhD Thesis, College of William and Mary, Williamsburg, VA

Crosby DS, Breaker LC, Gemmill WH (1993) A proposed definition for vector correlation in geophysics: theory and application. J Atmos Ocean Technol 10:355-367

Felger RS, Cliffton K, Regal PJ (1976) Winter dormancy in sea turtles: independent discovery and exploitation in the Gulf of California, México by two local cultures. Science 191: $283-285$

Forward RB, Tankersley RA (2001) Selective tidal-stream transport of marine animals. Oceanogr Marine Biol Annu Rev 39:305-353

Girard C, Sudre J, Benhamou S, Roos D, Luschi P (2006) Homing in green turtles Chelonia mydas: oceanic currents act as a constraint rather than as an information source. Mar Ecol Prog Ser 322:281-289

Godley BJ, Lima EHSM, Akesson S, Broderick AC and others (2003) Movement patterns of green turtles in Brazilian coastal waters described by satellite tracking and flipper tagging. Mar Ecol Prog Ser 253:279-288

> Hays GC, Marshall GJ, Seminoff JA (2007) Flipper beat frequency and amplitude changes in diving green turtles, Chelonia mydas. Mar Biol 150:1003-1009

Hildebrand B (2000) Waypoint +, p Computer Program

Hilton-Taylor C (2000) 2000 IUCN Red list of threatened species. IUCN, Gland, Switzerland and Cambridge, UK

Koch V, Nichols WJ, Brooks LB (2007) Population ecology of the green/black turtle (Chelonia mydas) in Bahía Magdalena, México. Mar Biol 153:35-46

Limpus CJ, Limpus DJ (2000) Mangroves in the diet of Chelonia mydas in Queensland, Australia. Mar Turtle Newsl 89:13-15

Limpus CJ, Couper PJ, Read MA (1994) The green turtle, Chelonia mydas, in Queensland: population structure in a warm temperate feeding area. Mem Queensl Mus 35:139-154

Luschi P, Hays GC, Papi F (2003a) A review of long-distance movements by marine turtles, and the possible role of ocean currents. Oikos 103:293-302

Luschi P, Sale A, Mencacci R, Hughes GR, Lutjeharms JRE, Papi F (2003b) Current transport of leatherback sea turtles (Dermochelys coriacea) in the ocean. Proc R Soc Lond 270(Supplement):S129-S132

Mancini A (2009) Pesca incidental o explotación directa Tasas y causas de mortalidad de las tortugas marinas en Baja California Sur. Posgrado en Ciencias Marinas y Costeras, UABCS, México

> Mellas EJ, Haynes JM (1985) Swimming performance and behavior of rainbow trout (Salmo garidneri) and white perch (Morone americana): effects of attaching telemetry transmitters. Can J Fish Aquat Sci 42:488-493

Mendonça MT (1983) Movements and feeding ecology of immature green turtles (Chelonia mydas) in a Florida lagoon. Copeia 4:1013-1023 
Mendonça MT, Ehrhart LM (1982) Activity, population size and structure of immature Chelonia mydas and Caretta caretta in Mosquito Lagoon, Florida. Copeia 1:161-167

Mortimer JA (1981) The feeding ecology of the West Caribbean green turtle (Chelonia mydas) in Nicaragua. Biotropica 13:49-58

Nichols WJ (2003) Biology and conservation of sea turtles in Baja California, México. PhD dissertation, University of Arizona

Ogden JC, Robinson L, Whitlock K, Daganhardt H, Cebula R (1983) Diel foraging patterns in juvenile green turtles (Chelonia mydas) in St. Croix, United States Virgin Islands. J Exp Mar Biol Ecol 66:199-205

Ramos SG, Santos LB (2005) Macroalgas asociadas a zona de alimentación de tortuga verde (Chelonia myadas agassizii) en el estero Banderitas, B.C.S. Undergraduate thesis, Universidad Autonoma de Baja California Sur (in Spanish)

Renaud ML, Carpenter JA (1994) Movements and submergence patterns of loggerhead turtles (Caretta caretta) in the Gulf of México determined through satellite telemetry. Bull Mar Sci 55:1-15

Renaud ML, Carpenter JL, Williams JA, Manzella-Tirpak SA (1995) Activities of juvenile green turtles, Chelonia mydas, in a jettied pass in south Texas. Fish Bull (Wash DC) 93: 586-593

Ross JP (1985) Biology of the green turtle, Chelonia mydas, on an Arabian feeding ground. J Herpetol 19:459-468

Schmid JR, Bolten AB, Bjorndal KA, Lindberg WJ (2002) Activity patterns of Kemp's ridley turtles, Lepidochelys kempii, in the coastal waters of the Cedar Keys, Florida. Mar Biol 140:215-228

Schmid JR, Bolten AB, Bjorndal KA, Lindberg WJ, Percival HF, Zwick PD (2003) Home range and habitat use by Kemp's ridley turtles in west-central Florida. J Wildl Manage 67:196-206

Seminoff JA (2000) Biology of the East Pacific green turtle, Chelonia mydas agassizii, at a warm temperate feeding

Editorial responsibility: Rory Wilson,

Swansea, UK area in the Gulf of California, México. PhD thesis, University of Arizona

Seminoff JA (2004) MTSG global assessment of green turtles (Chelonia mydas) for the IUCN Red List. IUCN Species Survival Commission, April 2004. Available at: http:// www.iucn-mtsg.org/red_list/cm/MTSG_chelonia_mydas_ assessment_april-2004.pdf

Seminoff JA, Jones TT (2006) Daily movements of green turtles (Chelonia mydas) at a temperate foraging area in the Gulf of California, México. Herpetol Cons Biol 1:81-86

Seminoff JA, Resendiz A, Nichols WJ (2002a) Diet of East Pacific green turtles (Chelonia mydas) in the central Gulf of California, México. J Herpetol 36:447-453

Seminoff JA, Resendiz A, Nichols WJ (2002b) Home range of green turtles (Chelonia mydas) at a coastal foraging area in the Gulf of California, México. Mar Ecol Prog Ser 242:253-265

Seminoff JA, Resendiz A, Nichols WJ, Jones TT (2002c) Growth rates of wild green turtles (Chelonia mydas) at a temperate foraging area in the Gulf of California, México. Copeia 2002:610-617

Sverdrup HU, Johnson MW, Fleming RH (1947) The oceans: their physics, chemistry and general biology, PrenticeHall, Englewood Cliffs, NJ

Taquet C, Taquet M, Dempster T, Soria M, Ciccione S, Roos D, Dagorn L (2006) Foraging of the green sea turtle Chelonia mydas on seagrass beds at Mayotte Island (Indian Ocean) determined by acoustic transmitters. Mar Ecol Prog Ser 306:295-302

Teaf CM (1980) A study of the tidally-oriented movements of the Atlantic stingray, Dasyatis sabina (LeSeuer) in Apalachee Bay, Florida. MSc thesis, Florida State University

- Whiting SD, Miller JD (1998) Short term foraging ranges of adult green turtles. J Herpetol 32:330-337

> Yasuda T, Arai N (2005) Fine-scale tracking of marine turtles using GPS-Argos PTTs. Zoolog Sci 22:547-553

> Yoda K, Naito Y, Sato K, Takahashi A and others (2001) A new technique for monitoring the behavior of free-ranging Adelie penguins. J Exp Biol 204:685-690

Submitted: December 21, 2007; Accepted: April 15, 2009

Proofs received from author(s): June 17, 2009 